\title{
Proses Pencapaian Self Efficacy pada Mahasiswa Tunanetra
}

\author{
Raiza Aulia ${ }^{1}$, Duta Nurdibyanandaru ${ }^{1}$ \\ ${ }^{1}$ Program Studi Magister Sains Psikologi (S2), Fakultas Psikologi, Universitas Airlangga, \\ Jl. Airlangga 4-6, Surabaya, 60286 Indonesia
}

Penulis untuk Korespondensi/E-mail: raiza.aulia-2019@psikologi.unair.ac.id

\begin{abstract}
Abstrak - Penelitian ini bertujuan untuk mengetahui proses pencapaian self efficacy mahasiswa tunanetra, dengan mendeskripsikan proses pencapaian self efficacy mahasiswa tunanetra yaitu proses kognitif, proses motivasi, proses afektif, dan proses seleksi. Empat proses pencapaian self efficacy tersebut menunjukkan peristiwa yang terjadi dalam individu memengaruhi situasi seperti kondisi emosional yang mementingkan diri sendiri daripada pengaruh orang lain [16]. Penelitian ini menggunakan pendekatan kualitatif desain studi kasus dengan teknik pengumpulan data melalui wawancara semi-terstruktur dan analisis data menggunakan teknik analisis tematik. Hasil penelitian ini menunjukkan ketiga partisipan memiliki proses yang berbeda. Dua partisipan laki-laki mengalami tahapan yang sama yaitu proses motivasi, proses kognitif, proses afektif dan proses seleksi. Pada partisipan perempuan tahapannya yaitu proses motivasi, proses kognitif, proses seleksi dan proses afektif.
\end{abstract}

Abstract - This study aims to determine the process of achieving self-efficacy of blind students, by describing the process of achieving self-efficacy of blind students, namely cognitive processes, motivational processes, affective processes, and selection processes. The four processes of achieving selfefficacy show that events that occur in individuals affect situations such as emotional conditions that are selfish rather than the influence of others [16]. This study uses a qualitative case study design approach with data collection techniques through semi-structured interviews and data analysis using thematic analysis techniques. The results of this study indicate the three participants have different processes. Two male participants experienced the same stages, namely the motivation process, cognitive process, affective process, and selection process. In female participants, the stages are motivation process, cognitive process, selection process, and affective process.

Keywords - Self Efficacy, Child with Special Need, Blind Student

\section{PENDAHULUAN}

$\mathrm{P}$ enyandang tunanetra adalah seorang individu yang memiliki ketajaman visual tidak lebih 20/200 atau kemampuan memulihkan kemampuan visualnya hanya mencapai 20 derajat [1]. Terdapat beberapa faktor yang memengaruhi penyandang tunanetra yakni salah satunya adalah gen, yaitu saat janin ibu kekurangan gizi atau malnutrisi dan bisa juga janin mengalami keracunan obat yang membuat bayi yang dikandungnya terlahir menjadi penyandang tunanetra [2]. Sebuah penelitian menjelaskan bahwa ketunanetraan sejak lahir membuat penyandang tunanetra merasa bahagia karena ia merasa tidak kehilangan sesuatu dalam dirinya, namun berbeda dengan penyandang tunanetra yang tidak mengalami ketunanetraan sejak lahir merasa tidak bahagia karena merasa dirinya kehilangan sesuatu dalam dirinya [3].

Terdapat beberapa penyandang tunanetra yang memiliki pendidikan rendah dan tidak mudah menjadi pekerjaan, karena akses pendidikan dan keterampilan penyandang tunanetra rendah dan berasal dari keluarga yang kurang sejatera [4]. Menurut Kementerian Pendidikan dan Kebudayaan hingga tahun 2016 sebanyak 88 persen penyandang disabilitas termasuk tunanetra belum mendapatkan akses pendidikan [5]. Pemerintah telah mengupayakan dengan cara meningkatkan pelayanan pendidikan khususnya terapat di perguruan tinggi yakni, perguruan tinggi inklusi yang mampu diakses oleh mahasiswa disabilitas khususnya oleh mahasiswa tunanetra. Hingga 11 tahun terakhir ini, mahasiswa tunanetra yang 
melanjutkan pendidikannya ke perguruan tinggi semakin meningkat dan bertambah [6]. Menurut Data Pertuni (Persatuan Tuna Netra Indonesia), pada tahun 2006, penyandang tunanetra memilih menjadi mahasiswa di perguruan tinggi berjumlah 250 orang dan mampu menunjukkan menempuh pendidikan yang lebih tinggi lagi untuk menunjukkan keterbatasan mereka tidak menghalangi keinginan dalam meraih pendidikan [6]. Salah satu universitas yang membuka jalur bagi mahasiswa difabel adalah Universitas Brawijaya (UB) di Malang yang memiliki kuota khusus bagi mahasiswa disabilitas yang lolos dari Seleksi Nasional Masuk Perguruan Tinggi Negeri (SNMPTN) [7].

Menjadi penyandang tunanetra bukan halangan untuk mampu menempuh pendidikan perguruan tinggi dan memiliki gelar. Didi Tarsidi, penyandang tunanetra total menjadi dosen di Jurusan Pendidikan Luar Biasa (PLB), dan sebagai dosen di sekolah Pasca-Sarjana Universitas Pendidikan Indonesia dengan gelar magister dan doktor di IKIP Bandung [8]. Kisah lain oleh Mimi Mariani Lusli yakni dosen di Universitas Atmajaya dengan gelar magisternya di Leeds University dan memiliki tempat konseling untuk ABK [9].

Sebuah penelitian yang membahas mengenai mahasiswa tunanetra subjective well-being [10]. Penelitian ini menunjukkan bahwa mahasiswa tunanetra memiliki efek yang positif dan negatif. Efek positif ditunjukkan dengan perasaan optimis, senang dan bangga, sedangkan efek negatif ditunjukkan seperti perasaan malu, sedih dan minder. Hal tersebut timbul dikarenakan terdapat faktor penerimaan diri terhadap keyakinan diri, dukungan sosial, pengungkapan diri dan kepedulian lingkungan [10].

Penelitian lain berjudul sikap dan kebiasaan belajar pada mahasiswa tunanetra [11]. Hasil penelitian menunjukkan mahasiswa tunanetra tidak segan bertanya saat mereka kurang akan suatu materi dalam perkuliahan, namun mereka belum bisa mengatur belajar yang tepat dan memperoleh motif belajar [11].

Terdapat penelitian mengenai efikasi diri akademik mahasiswa tunanetra [12] yakni penelitian untuk melihat self efficacy akademik mahasiswa tunanetra dengan menggunakan metode fenomenologi. Ada tiga partisipan mahasiswa aktif yang memiliki kriteria berbeda. Partisipan yang berbeda akan berpengaruh pada pembentukan self efficacy akademik mahasiswa tunanetra, karena perbedaan prestasi yang diraih sebelum perkuliahan. Pengaruh lain juga berasal dari lingkungan sekitar yang mampu membentuk self efficacy akademiknya sehingga yakin dapat menjalankan perkuliahan dengan baik [12].

Penelitian diatas merupakan pengkajian lebih lanjut dari penelitian sebelumnya yang dilakukan penulis dengan judul gambaran self efficacy mahasiswa tunanetra. Penulis melakukan penelitian yang lebih mendalam yakni penulis melihat proses pencapaian self efficacy mahasiswa tunanetra. Terdapat 4 tahapan yang akan dijabarkan oleh penulis tentang proses pencapaian self efficacy, sekaligus menjadikan sebuah keunikan karena penelitian ini belum pernah diteliti sebelumnya.

Penderita tunanetra atau gangguan penglihatan memiliki ciri utama yaitu penglihatan yang tidak normal. Adapun penjelasan dari bentuk-bentuk penglihatan yang tidak normal menurut Mangunsong [13] yaitu penglihatan yang samar untuk jarak dekat maupun jarak jauh, seperti pada kasus myopia, hyperopia ataupun astigmatismus. Masalah tersebut dapat diatasi dengan bantuan penggunaan kacamata. Penglihatan yang terbatas, seperti hanya mampu melihat tepi/perifer atau sentral. Hal ini berlaku pada salah satu bola mata atau kedua bola mata. Tidak dapat membedakan warna (buta warna). Penyesuaian terhadap cahaya terang dan gelap terhambat, terjadi pada orang yang lanjut usia. Sangat sensitif terhadap cahaya atau dalam ruangan yang terang atau disebut photopobic. Hal ini terjadi bagi orang albino, biasanya mereka kurang nyaman berada dalam ruangan yang terang.

Ciri lain dari gangguan penglihatan meliputi, terganggunya perkembangan bahasa, kemampuan intelektual, konseptual, mobilitas, prestasi akademik, penyesuaian sosial dan perilaku-perilaku stereotipik. Hal ini dihubungkan pada dampak gangguan penglihatan terhadap dimensi-dimensi tersebut, dan dapat dijabarkan setelah proses identifikasi [13].

Menurut Hadi [14] mengatakan bahwa istilah dari ketunanetraan sendiri disebut visual impairment. Hal ini menjelaskan tentang adanya dua jenis ketunanetraan yaitu blind (buta) dan kurang penglihatan (low vision). Pada jenis ketunanetraan blind (buta), seseorang lebih mengutamakan indera perabaan dalam pembelajarannya, sedangkan jenis kurang penglihatan seseorang masih dapat menggunakan penglihatannya sebagai pembelajarannya. Tunanetra sendiri merupakan individu yang kedua indera penglihatannya tidak 
berperan sebagai penyalur informasi seperti orang normal pada umumnya [2]. Mahasiswa tunanetra merupakan mahasiswa yang sedang menempuh pendidikan di perguruan tinggi yang memiliki keterbatasan pada penglihatannya.

Mahasiswa yang memiliki ketunanetraan mampu untuk melanjutkan perkuliahan, artinya sudah terdapat pandangan positif dari diri mereka sendiri untuk melanjutkan pendidikannya. Hal ini dibuktikan dari hasil survei Persatuan Tunanetra Indonesia (PERTUNI), yang mengatakan bahwa sudah ada 250 individu tunanetra yang menyelesaikan perkuliahan di Indonesia, sedangkan jumlah tunanetra yang ada di Indonesia sudah mencapai setengah persen dari masyarakat awas Indonesia [15].

Self efficacy merupakan kegigihan pada perilaku dan tindakan yang dijelaskan dalam penilaian dan harapan mengenai keterampilan, kemampuan serta kemungkinan untuk melewati tuntutan dan tantangan lingkungan agar mencapai keberhasilan. Berbagai faktor yang sama memainkan peran penting dalam penyesuaian psikologis dan disfungsi dalam intervensi terapeutik yang efektif untuk masalah emosional dan perilaku sebagai pertahanan dari self efficacy. Menurut Bandura [16] menyatakan bahwa dalam teori self efficacy, proses perubahan psikologis dan perilaku individu berfungsi melewati perubahan perasaan dari penguasaan pribadi atau keyakinan diri pada individu. Self efficacy awalnya tidak terlalu berkaitan dengan keyakinan seseorang dalam kemampuan seseorang untuk melakukan perilaku tertentu atau serangkaian perilaku yang diperlukan untuk menghasilkan sesuatu [16]. Pada akhirnya definisi self efficacy diperluas, dan mengacu pada "keyakinan masyarakat tentang kemampuan mereka untuk melakukan kontrol atas peristiwa yang mempengaruhi kehidupan mereka" [16] dan "keyakinan mereka dalam kemampuan mereka untuk memobilisasi motivasi, sumber daya kognitif, dan kursus tindakan yang diperlukan untuk melakukan kontrol atas tuntutan tugas" [16]. Menurut Bandura [16], penilaian keyakinan diri berhubungan "tidak dengan keterampilan yang dimiliki seseorang tetapi dengan penilaian tentang apa yang dapat dilakukan seseorang dengan keterampilan apa pun yang dimiliki". Bandura juga mengatakan bahwa "orang memproses, menimbang, dan mengintegrasikan beragam sumber informasi mengenai kemampuan mereka, dan mereka mengatur perilaku pilihan mereka dan pengeluaran usaha yang sesuai" [16]. Berdasarkan penjelasan diatas dapat disimpulkan bahwa self efficacy adalah keyakinan diri seseorang untuk dapat menempuh sesuatu yang diinginkannya.

Melanjutkan pendidikan untuk merubah masa depan yang lebih baik hingga ke perguruan tinggi menjadi sebuah keinginan dan keyakinan yang kuat oleh mahasiswa tunanetra sendiri untuk mengatakan bahwa ia mampu dan yakin atas usaha yang ia jalani di mulai dari self efficacy. Self efficacy menurut Ormrod [17] merupakan keyakinan seseorang yang mampu menjalankan perilaku tertentu dalam mencapai keberhasilan. Menurut Baron \& Byrne [18] self efficacy juga sebagai evaluasi individu terhadap kemampuan atau kompetensinya untuk melakukan sebuah penugasan, mencapai tujuan atau mengatasi hambatan. Menurut Ghufron \& Risnawita [19], menganggap bahwa efikasi diri adalah indikator positif dari core self evaluation untuk melakukan evaluasi diri yang berguna dalam pemahaman diri sendiri. Efikasi diri sebagai salah satu proses pengetahuan tentang diri atau self knowledge yang paling berpengaruh dalam kehidupan manusia sehari-hari, karena efikasi diri yang dimiliki akan memengaruhi individu dalam menentukan tindakan dan tantangan yang akan dihadapi untuk mencapai suatu tujuan. Self efficacy yang tinggi dimiliki para tunanetra yang berprestasi akademik. Sejauh ini self efficacy telah membahas masalah yang berkaitan dengan sifat alamiah dan sistem yang memiliki peran serta berpengaruh yang dapat dimainkan oleh individu melalui pengalamannya [16]. Dampak dari self efficacy akan memengaruhi bagaimana orang-orang merasakan, berpikir, memotivasi diri sendiri, dan bertindak. Self efficacy mengatur fungsi individu melalui empat proses yakni proses kognitif, proses motivasi, proses afektif, dan proses selektif. Proses kognitif merupakan keyakinan seseorang untuk memikirkan cara-cara yang dapat digunakan dan merancang tindakan yang akan diambil untuk mencapai tujuan yang diharapkan. Asumsi yang timbul pada proses ini kognitif adalah semakin efektif keyakinan seseorang dalam analisis berpikir dan dalam berlatih mengungkapkan ide- ide atau gagasan-gagasan pribadi, maka akan mendukung seseorang bertindak dengan tepat untuk mencapai tujuan yang diharapkan. Proses motivasi merupakan keyakinan seseorang untuk dapat memotivasi diri melalui pikirannya untuk melakukan tindakan dan keputusan dalam mencapai tujuan yang diharapkannya. Tiap orang berusaha memotivasi diri dengan menetapkan keyakinan pada tindakan yang akan dilakukan, merencanakan tindakan yang akan direalisasikan. Motivasi dalam self efficacy 
digunakan untuk memprediksikan kesuksesan dan kegagalan seseorang. Proses afeksi merupakan kemampuan dalam mengtasi emosi yang timbul dalam diri sendiri untuk mencapai tujuan yang diharapkan. Afeksi digunakan untuk mengontrol kecemasan dan perasaan depresif yang menghalangi pola-pola pikir yang benar untuk mencapai tujuan. Proses seleksi merupakan keyakinan seseorang untuk menyeleksi tingkah laku dan lingkungan yang tepat sehingga dapat mencapai tujuan yang diharapkan. Seleksi tingkah laku mempengaruhi perkembangan personal. Asumsi yang timbul pada proses ini adalah ketidakmampuan orang dalam melakukan seleksi tingkah laku membuat orang tidak percaya diri, bingung, dan mudah menyerah ketika menghadapi situasi konflik. Seleksi terhadap lingkungan dan aturan yang ada di dalamnya juga sangat berpengaruh terhadap self efficacy yang dimiliki oleh seseorang.

\section{METODE}

Penulis menggunakan pendekatan kualitatif dengan tipe penelitian studi kasus instrumental yang bertujuan mengetahui keunikan tiap partisipan mahasiswa tunanetra dalam mencapai prestasi akademiknya pada proses self efficacy lebih dalam. Tipe studi kasus instrumental bertujuan untuk memahami proses pencapaian self efficacy dilihat dari sudut pandang mahasiswa tunanetra yang menjadi partisipan dalam penelitian ini. Pemilihan partisipan dengan menggunakan teknik purposive yang bersumber pada kriteria-kriteria yang telah ditentukan oleh penulis, yaitu mahasiswa aktif penyandang tunanetra total, memiliki beprestasi dalam bidang akademik dengan miliki IPK minimal 3,00 serta mampu mendeskripsikan diri dan memiliki kemauan untuk mencapai prestasi tersebut. Penulis menggunakan teknik penggalian data wawancara secara mendalam pada setiap partisipan untuk memperoleh hasil yang mendalam tiap inidvidu. Wawancara semi-terstruktur memberikan kesempatan bagi peneliti untuk memahami dan mendengarkan segala hal yang dikatakan oleh partisipan dari pengalaman hidupnya, murni berdasarkan sudut pandang partisipan [20]. Hasil wawancara dianalisis menggunakan analisis tematik yaitu proses mengkode informasi yang dapat menghasilkan daftar tema, model tema, atau indikator yang kompleks [21]. Tema yang dihasilkan dapat mendeskripsikan fenomena yang terjadi secara maksimal serta membantu proses interpretasi fenomena [21]. Terdapat tiga cara untuk menganalisis data secara tematik [21] yaitu theory driven, prior research-driven, dan data-driven. Pada penelitian ini, penulis menggunakan analisis data berupa theory-driven karena mempertimbangkan proses sejak awal menggunakan pedoman wawancara dan analisis akan dilanjutkan menggunakan dasar teori tersebut, agar data yang ditemukan lebih tersistematis.

\section{HASIL DAN PEMBAHASAN}

Hasil dari penelitian ini menunjukkan mahasiswa tunanetra memunculkan proses-proses dalam mencapai self efficacy yang meliputi proses kognitif, proses motivasi, proses afektif, dan proses seleksi [16]. Ketiga partisipan mahasiswa tunanetra memiliki perbedaan tahapan prosesnya untuk mencapai self efficacy. Hasil analisis data yang diperoleh oleh penulis pada mahasiswa tunanetra dalam proses kognitif yakni keyakinan individu untuk merancang sebuah tindakan dalam mencapai tujuan yang diharapakan melalui proses berpikir [16]. Partisipan memiliki keinginan dan kemauan diri sendiri untuk melanjutkan pendidikan ke perguruan tinggi sejak menempuh pendidikan sekolah. Kedua partisipan laki-laki memiliki keinginan berkuliah sejak duduk di SMP sedangkan satu partisipan perempuan memiliki keinginan untuk melanjutkan pendidikan perguruan tinggi pada saat SMA. Walaupun usia melebihi teman-teman kelas pada umumnya namun pada akhirnya mereka mampu mengikuti kegiatan belajar mengajar dengan baik dilingkup SLB dan inklusi. Salah satu partisipan laki-laki sering direndahkan oleh keluarga besar ibunya. Namun, ibu partisipan menguatkan dan selalu memberikan support hingga mampu menjalani pendidikan seperti anak normal. Partisipan juga pernah ditolak masuk Perguruan Tinggi Negeri sebanyak 4 kali dan sempat putus asa, namun akhirnya ia mencoba peruntungan masuk ke Perguruan Tinggi Swasta kemudian lolos. Salah satu partisipan perempuan pernah mengalami putus sekolah 3 tahun pada saat awal menjadi penyandang tunanetra di usia 12-15 tahun. Keluarga dan partisipan masih belum bisa menerima kenyataan yang ada, hingga akhirnya di tahun ke 3 orang tua partisipan mendorong kembali partisipan untuk bersekolah di Sekolah Luar Biasa tingkat Sekolah Menengah Pertama. Pada partisipan ketiga, ia selalu di support ibunya dari menemani kursus piano, bersepeda sendiri dan sedikit memaksakan partisipan bermain dengan anak-anak normal seusianya. Saat ini ketiga partisipan berusaha untuk sesegera mungkin menyelesaikan pendidikan $\mathrm{S} 1$ dan 
berharap mendapatkan beasiswa untuk pendidikan S2.

Pada perkuliahan, mahasiswa tunanetra selalu mengomunikasikan dan bernegosiasi dengan dosen tentang tugas yang tidak mudah dijangkau bagi tunanetra. Partisipan meminta penugasan lain dan salah satu partisipan perempuan didampingi volunteer untuk membantunya dalam penugasan yang dalam perkuliahan. Semua partisipan memiliki alat bantu di handphone dan laptopnya dengan aplikasi bernama jaws yang mampu mengeluarkan suara dan memahamkan materi dari suara yang dikeluarkan oleh aplikasi di laptop dan handphone tersebut. Hal tersebut dibuktikan bahwa mahasiswa tunanetra mampu mengupayakan berbagai cara agar memperoleh penilaian yang baik dengan mencapai IPK diatas 3,00.

Proses motivasi adalah sebuah keyakinan dalam individu untuk memotivasi melalui pemikirannya dalam bertindak dan mengambil keputusan sehingga tercapaianya tujuan yang diharapkan atau diinginkan [16]. Partisipan mampu berprestasi dibidang luar akademik yakni memperoleh juara peringkat 1 lomba mengarang se-Asia Pasific saat menunggu waktu diterima dibangku perkuliahan. Partisipan perempuan mampu mengarang dan menerbitkan buku pada saat SMA, serta salah satu partisipan menjadi siswa pilihan untuk dikirim ke Jerman pada mata pelajaran Bahasa Jerman di bangku SMA. Tidak hanya itu, dua partisipan laki-laki juga mencari penghasilan dari menjadi tukang pijat dan pemain band. Penghasilan yang ada diberikan kepada ibu dan biaya mereka untuk berkuliah.

Proses afektif adalah sebuah kemampuan individu untuk mengendalikan emosi yang muncul dalam dirinya serta mengontrol kecemasan dan perasaan depresif sehingga mampu mencapai tujuan yang diinginkan [16]. Pada hasil ditunjukkan, saat partisipan mengalami rasa sedih dikarenakan perlakuan teman-teman, keinginan yang tidak tercapai karena nilai kurang baik dan lain sebagainya, mereka menghibur diri dengan mendengarkan lagu dan menyanyikan lagu. Menurut partisipan, kegiatan tersebut dapat menumbuhkan semangat kembali dan mulai berpikir lebih jernih lagi.

Proses seleksi adalah sebuah keyakinan individu dalam menyeleksi tingkah laku serta lingkungan yang tepat memengaruhi perkembangan personal untuk mencapai tujuan yang diinginkan [16]. Pada saat partisipan masuk ke bangku sekolah, salah satu partisipan selalu dibimbing oleh ibunya mulai dari persiapan hingga diantar ke sekolah sampai SMA. Partisipan laki-laki lain pernah meminta ibunya untuk tidak mengantarnya sekolah dan naik bemo bersama temannya, namun ibunya berpura-pura mengizinkan dan mengikuti partisipan dari belakang. Pada saat masuk bangku SMA, ketiga partisipan mengikuti pendidikan inklusi dan partisipan tidak jarang dibantu oleh teman-temannya di kelas. Mulai dari memperkenalkan lambanglambang matematika dan menemani mengganti pakaian olahraga. Salah satu partisipan perempuan pernah menjadi gunjingan teman-temannya saat salah satu temannya menemani mengganti pakaian. Ada teman yang mengasihani, ada yang keberatan untuk menunggu partisipan. Partisipan dalam penelitian ini sedikit kesulitan dalam mencari teman dalam perkuliahan. Terkadang mereka menunggu teman yang merasa dekat dengannya untuk masuk ke perkuliahan itu, jika temnnya tidak masuk dalam kelas tersebut maka ia tidak mengikuti perkuliahan di hari itu. Pada pasrtisipan yang lain ia memiliki pelayanan volunteer yang disediakan pihak universitas. Dimana hampir seluruh aktivitas dalam perkuliahan didampingi oleh volunteer, terkadang hal tersebut memengaruhi partisipan dalam membangun lingkungan pertemanan dalam kampus. Sedangkan pada dua partisipan yang lain tidak diberi pelayanan volunteer, sehingg mereka tertantang untuk mendapat dan mencari kelas sendiri, teman hingga dosen. Tantangan yang diperoleh partisipan saat kuliah juga beraneka ragam. Mulai dari dibohongi karena penugasan hingga penipuan dalam bentuk materi.

Proses kognitif adalah keyakinan individu dalam merancang sebuah tindakan untuk mencapai tujuan yang diinginkan melalui proses berpikir [16]. Partisipan memiliki keinginan dan kemauan diri sendiri untuk melanjutkan pendidikan ke perguruan tinggi sejak menempuh pendidikan sekolah. Kedua partisipan laki-laki memiliki keinginan berkuliah sejak duduk di SMP sedangkan satu partisipan perempuan memiliki keinginan untuk melanjutkan pendidikan perguruan tinggi pada saat SMA. Walaupun usia melebihi teman-teman kelas pada umumnya namun pada akhirnya mereka mampu mengikuti kegiatan belajar mengajar dengan baik dilingkup SLB dan inklusi. Salah satu partisipan laki-laki sering direndahkan oleh keluarga besar ibunya. Namun, ibu partisipan menguatkan dan selalu memberikan support hingga mampu menjalani pendidikan seperti anak normal. Partisipan juga pernah ditolak masuk Perguruan Tinggi Negeri sebanyak 4 kali dan sempat putus asa, 
namun akhirnya ia mencoba peruntungan masuk ke Perguruan Tinggi Swasta kemudian lolos. Salah satu partisipan perempuan pernah mengalami putus sekolah 3 tahun pada saat awal menjadi penyandang tunanetra di usia 12-15 tahun. Keluarga dan partisipan masih belum bisa menerima kenyataan yang ada, hingga akhirnya di tahun ke 3 orang tua partisipan mendorong kembali partisipan untuk bersekolah di Sekolah Luar Biasa tingkat Sekolah Menengah Pertama. Pada partisipan ketiga, ia selalu di support ibunya dari menemani kursus piano, bersepeda sendiri dan sedikit memaksakan partisipan bermain dengan anak-anak normal seusianya. Partisipan telah memiliki rencana pendidikan yang mereka pilih untuk masa depan yang labih baik walaupun terdapat keterbatasan penglihatan. Hal tersebut dibuktikan dengan kesungguhan ketiga partisipan mampu meraih IPK 3,00 mulai dari masuk kuliah hingga saat ini memasuki masa skripsi. Salah satu partisipan yang berkuliah di PTS memperoleh IPK tertinggi 3,90 dan terendah 3,08. Kedua partisipan yang berkuliah di PTN memperoleh IPK tertinggi 3,51 dan terendah 3,08. Ketiga partisipan juga telah mengupayakan mampu mengikuti penugasan didalam perkuliahan dengan menggunakan aplikasi jaws sebagai penerjemah dalam laptop dan handphone nya. Partisipan akan senang jika mendapatkan soft file oleh dosen karena ia dapat mempelajari dan dapat diterjemahkan oleh aplikasi yang dimilikinya.

Aplikasi pada jaws berupa perangkat lunak dapat membantu penyandang tunanetra untuk membacakan setiap tulisan di laptop dalam bentuk audio [22]. Selain menggunakan jaws, beberapa mahasiswa tunanetra juga merekam suara dosen saat pemberian materi untuk dapat memahami materi tersebut. Saat ini partisipan memiliki keinginan mampu lulus dengan baik dan memperoleh beasiswa S2 diluar negeri.

Partisipan terkadang kurang menjangkau penugasan karena keterbatasan yang ada, mereka selalu mengomunikasikan hal tersebut kepada dosen. Terdapat dosen yang mentolerir penugasan dengan mengganti penugasan yang dapat dijangkau oleh partisipan, namun ada dosen yang tidak mengganti penugasan. Salah satu partisipan mengomunikasikan kepada volunteer terkait penugasan yang tidak dapat dijangkau. Ketiga partisipan memiliki pemikiran inferensial pada proses kognitif dimana mereka dapat memprediksi situasi yang akan terjadi, serta dapat dijadikan tantangan dalam keterbatasannya [16]. Pada ketiga partisipan terdapat kesulitan yang mampu dihadapi partisipan pada saat menerima materi pembelajaran. Kesulitan dari ketiga partisipan tidak terlepas dari usaha dan kegigihan partisipan dalam mencapai tujuan perkuliahan. Terbukti bahwa disetiap partisipan mampu menunjukkan performa akademik yang baik dalam self efficacy pada akademik [23].

Pada proses motivasi pada mahasiswa tunanetra, dimana yang terjadi oleh mahasiswa tunanetra dalam penelitian ini ketiga mahasiswa tunanetra berjuang untuk dapat berkuliah karena ingin memiliki kehidupan yang lebih baik nantinya. Partisipan mampu berprestasi dibidang luar akademik yakni memperoleh juara peringkat 1 lomba mengarang seAsia Pasific saat menunggu waktu diterima dibangku perkuliahan. Partisipan perempuan mampu mengarang dan menerbitkan buku pada saat SMA, serta salah satu partisipan menjadi siswa pilihan untuk dikirim ke Jerman pada mata pelajaran Bahasa Jerman di bangku SMA. Tidak hanya itu, dua partisipan laki-laki juga mencari penghasilan dari menjadi tukang pijat dan pemain band Penghasilan yang ada diberikan kepada ibu dan biaya mereka untuk berkuliah.

Salah satu partisipan pernah ditolak empat kali masuk PTN dan PTS satu kali di Surabaya. Partisipan tersebut sering direndahkan oleh keluarga besarnya karena keterbatasannya, namun keinginannya dan kegigihan yang kuat ia mampu untuk masuk PTS yang ada di Jember untuk menempuh pendidikan perguruan tinggi dan dapat ia buktikan hingga saat ini mampu mengikuti perkuliahan dengan baik hingga memperoleh IPK diatas 3,00. Hal itu terdapat dalam memotivasi melalui pemikirannya dalam bertindak dan mengambil keputusan agar tercapaianya suatu tujuan yang diharapkan [16]. Salah satu partisipan lain menjadi anggota band dan menerima banyak tawaran untuk mengisi acara dengan keterbatasannya menjadi penyandang tunanetra. Penghasilan yang didapatkan dari event tersebut untuk menghidupi kebutuhan sehari-hari ibu dan adiknya, serta untuk membayar kuliahnya. Pekerjaan yang dilakukan partisipan tersebut dengan memikirkan tentang bagaimana mencari part-time job untuk mengembangkan kemampuan dalam memecahkan permasalahan personal [24]. Partisipan dalam penelitian ini memiliki keahliannya masing-masing yaitu mampu menerbitkan buku, mendapatkan juara 1 lomba mengarang se Asia Pasific tahun 2014 dan menjadi anggota band hingga memiliki impian mengadakan konser musik di luar negeri. Selain memiliki keahlian, partisipan berharap nantinya bagi orang lain dan dapat 
meningkatkan derajat orang tua dan keluarga. Ibu, ayah dan saudara kandung partisipan berharap bahwa mereka dapat memperoleh pendidikan yang sama dan dapat melanjutkan pendidikan hingga ke S2 sampai ke luar negeri.

Salah satu partisipan tidak ingin menggunakan tongkat karena merasa mampu dan familiar dengan lokasi tersebut. Perjalanan yang familiar dapat dilewatinya karena seringnya melewati jalan yang sama secara berulang [25]. Partisipan akan tahu arah kemana akan berjalan, mengerti untuk belok kanan dan kiri, tanjakan dan lain sebagainya. Namun, kedua partisipan masih menggunakan tongkat sebagai penunjuk arah berjalan, karena belum mampu dan belum mempunyai keyakinan akan kondisi lingkungan disekitarnya.

Proses afeksi digunakan untuk mengontrol kecemasan dan perasaan depresif yang menghalangi pola-pola pikir yang benar untuk mencapai tujuan [16] yang terjadi pada partisipan dalam penelitian ini yakni pada saat partisipan mengalami kesedihan atau down, mereka mendengarkan lagu, bernyanyi hingga mengarang lagu untuk menghilangkan rasa sedih, tertekan dan hal lain yang membuat mereka merasa tidak nyaman. Partisipan memiliki cara menghibur diri saat merasa gelisah, cemas dan khawatir yaitu dengan mendengarkan musik, bernyanyi hingga mengarang sebuah lagu. Alunan musik dapat berpengaruh pada pikiran sehingga dapat merasakan efek dari perasaan gembira, sedih, terharu, terasa sunyi, semangat, dan teringat akan masa lalu [26].

Individu yang mengalami ketunanetraan sejak lahir akan lebih bahagia menerima keadaan sebagai penyandang tunanetra, karena tidak akan merasakan kehilangan sesuatu yang ada dalam dirinya. Lain halnya dengan individu tunanetra yang sebelumnya dapat melihat, mereka akan merasa tidak bahagia [3]. Pernyataan tersebut sesuai pada beberapa partisipan mahasiswa tunanetra yang sebelumnya dapat melihat, individu tersebut merasa minder, kurang terbuka dalam bercerita tentang kehidupan lainnya. Namun, pada salah satu partisipan mahasiswa tunanetra yang menjadi penyandang tunanetra sejak lahir menunjukkan keyakinan dan sikap acuh tak acuh saat dihadapkan pada kesulitan.

Pada proses seleksi, dimana tingkah laku memengaruhi perkembangan personal dari individu [16]. Pada saat partisipan masuk ke bangku sekolah, salah satu partisipan selalu dibimbing oleh ibunya mulai dari persiapan hingga diantar ke sekolah sampai SMA. Partisipan laki-laki lain pernah meminta ibunya untuk tidak mengantarnya sekolah dan naik bemo bersama temannya, namun ibunya berpura-pura mengizinkan dan mengikuti partisipan dari belakang. Pada saat masuk bangku SMA, ketiga partisipan mengikuti pendidikan inklusi dan partisipan tidak jarang dibantu oleh teman-temannya di kelas. Mulai dari memperkenalkan lambanglambang matematika dan menemani mengganti pakaian olahraga. Salah satu partisipan perempuan pernah menjadi gunjingan teman-temannya saat salah satu temannya menemani mengganti pakaian. Ada teman yang mengasihani, ada yang keberatan untuk menunggu partisipan. Partisipan dalam penelitian ini sedikit kesulitan dalam mencari teman dalam perkuliahan. Terkadang mereka menunggu teman yang merasa dekat dengannya untuk masuk ke perkuliahan itu, jika temannya tidak masuk dalam kelas tersebut maka ia tidak mengikuti perkuliahan di hari itu. Pada pasrtisipan yang lain ia memiliki pelayanan volunteer yang disedikan pihak universitas. Dimana hampir seluruh aktivitas dalam perkuliahan didampingi oleh volunteer, terkadang hal tersebut memengaruhi partisipan dalam membangun lingkungan pertemanan dalam kampus. Namun, pada dua partisipan yang lain tidak diberi pelayanan volunteer, sehingg mereka tertantang untuk mendapat dan mencari kelas sendiri, teman hingga dosen. Tantangan yang diperoleh oleh partisipan juga beraneka ragam. Mulai dari dibohongi karena penugasan hingga penipuan dalam bentuk materi.

Beberapa mahasiswa tunanetra terbukti tidak memiliki volunteer, sehingga mereka mengalami kesulitan dalam mencari informasi dan bantuan penugasan yang tidak dapat dijangkau oleh mahasiswa tunanetra, sedangkan mahasiswa tunanetra lainnya memiliki volunteer untuk membantunya dalam proses perkuliahan seperti penugasan maupun bantuan pemberian materi di kelas.

Volunteer merupakan seseorang yang membantu orang lain yang memiliki keterbatasan secara sukarela dalam meningkatkan kesejahteraan orang lain tersebut [27]. Pada penelitian ini, partisipan mahasiswa tunanetra sedikit mengalamai kesulitan dalam relasi pertemanan di lingkungan perkuliahan. Terkadang mahasiswa tunanetra menunggu teman dekatnya masuk perkuliahan hari itu, jika tidak ada teman dekatnya maka dia tidak mengikuti kelas tersebut. Jauh berbeda dengan mahasiswa tunanetra yang memiliki pelayanan volunteer dari pihak kampus. Seluruh aktivitas perkuliahan akan 
didampingi oleh volunteer, hal ini akan memengaruhi partisipan untuk tidak mengenal lingkungan kampus dengan sendirinya. Relasi dalam hal pertemanan akan mampu memberikan motivasi saat berapa di area kampus dengan perasaan nyaman [28].

Namun, beberapa partisipan mahasiswa tunanetra mengalami permasalahan dengan teman sekelas, yaitu mahasiswa tunanetra ditinggal disuatu tempat sehingga dia memesan ojek online dan mahasiswa tunanetra lainnya dimanfaatkan serta ditipu saat bekerjasama dalam sebuah bisnis. Pada peristiwa ini, beberapa mahasiswa tunanetra tersebut terbukti mengalami keterasingan dalam menjalin relasi pertemanan dengan orang awas, sehingga mahasiswa tunanetra harus dapat lebih mandiri dalam membentuk perilaku positif [29].

Perbandingan proses pencapaian Self Efficiacy secara singkat dapat dilihat pada Tabel 1.

Tabel. 1 Tabel Komparasi Proses Pencapaian Self Efficacy

\begin{tabular}{|c|c|c|c|c|c|}
\hline \multirow{2}{*}{$\begin{array}{l}\text { Partisipan } \\
\text { Penelitian }\end{array}$} & \multirow[t]{2}{*}{ Ciri Utama } & \multicolumn{4}{|c|}{ Proses Pencapaian Self Efficacy } \\
\hline & & Kognitif & Motivasi & Afektif & Seleksi \\
\hline $\begin{array}{c}\text { Partisipan } 1 \\
\text { Laki-laki }\end{array}$ & Pendidikan & $\begin{array}{l}\text { Partisipan memiliki } \\
\text { keinginan } \\
\text { melanjutkan } \\
\text { pendidikan sampai } \\
\text { S2 }\end{array}$ & $\begin{array}{c}\text { Menaikkan } \\
\text { derajat keluarga } \\
\text { terutama ibu } \\
\text { (bercerai) }\end{array}$ & $\begin{array}{c}\text { Bermain musik dan } \\
\text { bernyanyi jika } \\
\text { merasa sedih atau } \\
\text { direndahkan orang } \\
\text { lain }\end{array}$ & $\begin{array}{c}\text { Partisipan } \\
\text { ditinggalkan } \\
\text { temannya di area } \\
\text { universitas }\end{array}$ \\
\hline $\begin{array}{c}\text { Partisipan } 2 \\
\text { Laki-laki }\end{array}$ & Pendidikan & $\begin{array}{l}\text { Partisipan memiliki } \\
\text { keinginan } \\
\text { melanjutkan } \\
\text { pendidikan sampai } \\
\text { S2 }\end{array}$ & $\begin{array}{l}\text { Menaikkan } \\
\text { derajat keluarga } \\
\text { (almarhum } \\
\text { ayah) dan ibu }\end{array}$ & $\begin{array}{l}\text { Bermain musik dan } \\
\text { bernyanyi jika } \\
\text { merasa sedih atau } \\
\text { direndahkan orang } \\
\text { lain }\end{array}$ & $\begin{array}{c}\text { Partisipan } \\
\text { dibohongi } \\
\text { temannya dalam hal } \\
\text { keuangan }\end{array}$ \\
\hline $\begin{array}{l}\text { Partisipan } 3 \\
\text { Perempuan }\end{array}$ & Keluarga & $\begin{array}{l}\text { Keluarga mendorong } \\
\text { partisipan untuk } \\
\text { melanjutkan sekolah }\end{array}$ & $\begin{array}{l}\text { Latar belakang } \\
\text { keluarga } \\
\text { partisipan } \\
\text { adalah } \\
\text { mengedepankan } \\
\text { pendidikan } \\
\text { (almarhum ibu) }\end{array}$ & $\begin{array}{c}\text { Bermain musik dan } \\
\text { bernyanyi jika } \\
\text { merasa sedih atau } \\
\text { direndahkan orang } \\
\text { lain }\end{array}$ & $\begin{array}{c}\text { Partisipan } \\
\text { mendengar } \\
\text { pembicaraan } \\
\text { temannya bahwa, } \\
\text { partisipan } \\
\text { merepotkannya }\end{array}$ \\
\hline
\end{tabular}

\section{KESIMPULAN}

Masing-masing partisipan memiliki proses pencapaian self efficacy yang memiliki kaitan dengan empat proses yakni proses kognitif, motivasi, afektif dan seleksi. Ketiga partisipan memiliki tahapan yang berbeda-beda dikarenakan latar belakang dan peran orang tua tunggal pada seluruh partisipan. Kedua partisipan laki-laki yang tinggal dengan orang tua tunggal ibu diberikan stimulus lebih dan kemandirian sehingga sejak partisipan mengalami tunanetra atau menjadi penyandang tunanetra mereka mampu mengikuti pembelajaran yang ada dilingkungan maupun pendidikan. Sedangkan salah satu partisipan perempuan yang tinggal dengan orang tunggal ayah kurang terbuka dan cenderung menutupi kebutuhannya atau ragu meminta bantuan orang lain. Partisipan pernah putus sekolah selama 3 tahun karena ayah partisipan masih belum memperbolehkan putrinya mengikuti atau masuk komunitas tunanetra. Pada akhirnya ayahnya mulai mengizinkan putrinya dan dibantu kakak partisipan yang mendorong adiknya mengenyam pendidikan. Pada saat kuliah, ia telah memiliki volunteer yang telah membantunya untuk semua matakuliah dan penugasan, yang disediakan oleh universitas seperti ada tidaknya volunteer serta toleransi dari lingkungan universitas juga memengaruhi empat 
proses pencapaian self efficacy pada mahasiswa tunanetra.

Pada proses kognitif ditunjukkan pada partisipan memiliki IPK minimal 3,00, mengikuti pembelajaran dalam perkuliahan, mengikuti beberapa kegiatan organisasi dan kegiatan di luar kampus dan berkomitmen untuk lulus $\mathrm{S} 1$ dan berkeinginan melanjutkan S2 dengan beasiswa. Pada proses motivasi, partisipan memiliki keahlian dalam beberapa bidang. Psartisipan ini mengarahkan hobi mengarang untuk menjadikannya sebuah buku dan mengikutkan perlombaan hingga memenangkan juara Asia Pasific yang ditampilkan di Jepang. Terdapat pula keahlian bermain musik yang dapat dijadikan ladang penghasilan untuk menghidupi ibu dan saudaranya. Partisipan melakukan hobinya berkisar mulai usia 5 tahun hingga saat ini.

Proses afektif ditunjukkan oleh partisipan dalam berusaha mengatasi dirinya sendiri saat merasa sedih dengan cara mendengarkan lagu dan bernyanyi. Dukungan dari orang tua dan teman sesama tunanetra juga dapat mendorong tingkat motivasi partisipan. Partisipan ini juga memiliki perbedaan proses afektif yang berbeda antara dua partisipan yang menjadi penyandang tunanetra saat usia remaja dan satu partisipan yang menjadi penyandang tunanetra mulai dari lahir. Pada partisipan yang lahir dengan tunanetra merasa hidupnya lebih santai dan cuek dalam menghadapi permasalahan, namun berbeda dengan dua partisipan yang menjadi penyandang tunanetra saat remaja lebih mudah tersinggung dan sensitif. Terakhir proses seleksi, dimana mahasiswa tunanetra dapat memberikan manfaat bagi lingkungannya. Partisipan juga mampu menunjukkan potensinya dilingkungan luar bahwa ia dapat melakukan apa yang dilakukan orang normal lainnya. Namun, dalam hal pertemanan partisipan kesulitan untuk membangun relasi dengan teman atau orang baru.

\section{Saran Bagi Partisipan Penelitian}

Pada proses pencapaian self efficacy yang didalamnya terdapat 4 tahapan yakni proses kognitif, proses motivasi, proses afektif dan proses seleksi, masing-masing partisipan diharapkan dapat berkomitmen dengan menyelesaikan perkuliahan S1 dan dapat melanjutkan studi S2 dengan self efficacy yang lebik baik. Ketiga partisipan diharapkan mampu mempertahankan serta meningkatkan self efficacynya untuk pendidikan selanjutnya.

\section{Saran Bagi Mahasiswa Tunanetra}

Penelitian ini mampu memberikan informasi bagi partisipan mengenai proses pencapaian self efficacy dengan ketiga contoh partisipan penelitian. Tanpa berniat menggeneralisasi dan meninggalkan keunikan masing-masing partisipan dalam melakukan segala perilakunya dalam mengupayakan self efficacynya.

\section{Saran Bagi Penelitian Selanjutnya}

Penulis yang memiliki ketertarikan mengenai proses pencapaian self efficacy pada mahasiswa tunanetra yang dapat melakukan penelusuran lebih mendalam seperti dapat menambah fokus penelitian tentang faktor-faktor self efficacy dan diharap dapat menambah metode penggalian data observasi dan catatan lapangan untuk memperkuat landasan penelitiannya.

\section{UCAPAN TERIMA KASIH}

Terima kasih kepada Allah SWT yang telah memberikan peneliti kesempatan untuk mengetahui lebih dalam mengenai self efficacy pada mahasiswa tunanetra. Terima kasih pada seluruh partisipan dan ijin yang diberikan kepada peneliti untuk menggali informasi mengenai self efficacy partisipan. Tidak hanya itu peneliti mengucapkan terima kasih kepada kedua orang tua, sahabat dan dosen pembimbing yang telah memberikan saran atas hasil peneliti berikan untuk menjadi lebih baik lagi.

\section{REFERENSI}

[1] D. P. Hallahan, J. M. Kauffman, Exceptional Children: Introduction to Special Education (6th ed.), Pearson, Boston, 1994.

[2] R. Aulia, Skripsi, Gambaran Self Efficacy pada Mahasiswa Tunanetra, Fakultas Psikologi Universitas Airlangga, Surabaya, 2018.

[3] E. Herlina, Heryati, S. Chotidjah, Profil Kebutuhan Psikologis Mahasiswa Tunanetra di Fakultas Ilmu Pendidikan Universitas Pendidikan Indonesia, Bandung, 2008.

[4] A. Sunaryo, Jutaan Tunanetra Berpendidikan Rendah Kesulitan Cari Pekerjaan, https://www.merdeka.com/peristiwa/jutaantunanetra-berpendidikan-rendah-kesulitancari-pekerjaan.html, 2016. (Diakses pada tanggal 20 Mei 2020)

[5] J. H. Kusmargana, Jutaan Tuna Netra di Indonesia, Belum Dapat Akses Pendidikan, https://www.cendananews.com/2017/04/jutaan -tuna-netra-di-indonesia-belum-dapat-akses- 
pendidikan.html, 2017. (Diakses pada tanggal 21 Mei 2020)

[6] D. A. Hapsari, Jumlah Mahasiswa Tuna Netra di Indonesia Bertambah, https://malang voice.com/jumlah-mahasiswa-tuna-netraindonesia-bertambah/, 2017. (Diakses pada tanggal 26 Juni 2020)

[7] M. Attamami, Mahasiswa difabel bisa kuliah di Universitas Brawijaya, https://jogja. antaranews.com/berita/298959/mahasiswadifabel-bisa-kuliah-di-universitas-brawijaya, 2012. (Diakses pada tanggal 24 Juni 2020)

[8] N. Rizal, Panduan Layanan Mahasiswa Disabilitas di Perguruan Tinggi, https://issuu.com/nasrulrizal2/docs/panduan_la yanan mahasiswa disabilit, 2018. (Diakses pada tanggal 24 Mei 2020).

[9] D. Ginanjar, Kehilangan Penglihatan, Mimi Mariani Lusli Tetap Gigih di Dunia Pendidikan, https://www.jpnn.com/news/kehilanganpenglihatan-mimi-mariani-lusli-tetap-gigih-didunia-pendidikan, 2011. (Diakses pada tanggal 20 Mei 2020)

[10] C. D. Steven, D. R. Sawitri, Bersyukur di Tengah Sedih dan Senangku: Studi Kualitatif Subjective Well-Being pada Mahasiswa Tunanetra, Jurnal Empati. 5(3), 439-442, 2016.

[11] N. D. Khoeriah, A. N. Hidayat, Sikap dan Kebiasaan Belajar Mahasiswa Tunanetra Prodi PLB FKIP UNINUS, Jurnal Rehabilitasi dan Remediasi. 25(1), 1-5, 2016.

[12] M. Bahar, Y.I. Aviani, Efikasi Diri Akademik Mahasiswa Tunanetra, Jurnal Riset Aktual Psikologi. 6(2), 169-180, 2015.

[13] F. Mangunsong. Psikologi dan Pendidikan Anak berkebutuhan khusus, Jilid kedua, Penerbit LPSP3 UI, Jakarta, 2014.

[14] P. Hadi, Kemandirian Tunanetra, Departemen Pendidikan Nasional, Direktorat Jenderal Pendidikan Tinggi, Direktorat Pembinaan Pendidikan Tenaga Kependidikan dan Ketenagakerjaan Perguruan Tinggi, Jakarta, 2005.

[15] Risma, Aksesibilitas Kampus bagi Mahasiswa Tunanetra, http://www.kartunet.com/ aksesibilitaskampus-bagi-mahasiswatunanetra199. 2013. (Diakses pada tanggal 20 Mei 2020)
[16] A. Bandura, Self efficacy: The Exercise of Control, W.H. Freeman and Company, New York 1997.

[17] J. E. Ormrod, Psikologi Pendidikan: Membantu Siswa Tumbuh dan Berkembang, Jilid 1, (A. Kumara, Ed.), Erlangga, Jakarta, 2010.

[18] R. A. Baron, D. Byrne, Psikologi Sosial Jilid 2, Erlangga, Jakarta, 2012

[19] M. N. Ghufron, R. Risnawita, Teori-Teori Psikologi, Ar-Ruzz Media, Yogyakarta, 2010.

[20] H. Herdiansyah, Metodologi Penelitian Kualitatif untuk Ilmu Psikologi. Salemba Humanika, Jakarta, 2015.

[21] R. E. Boyatzis, Transforming Qualitative Information: Thematic Analysis and Code Development, Sage pub, Thousand Oaks, 1998.

[22] M. R, Nababan, R. A. Nugroho, Sunardi, Working Paper at International Conference on Language and Culture at Work, Universitas Sebelas Maret, Surakarta, 2011.

[23] J. Feist, G. J. Feist, Theories of Personality (6th ed.), McGraw-Hill Companies, Inc, United States, 2006.

[24] D. H. Powell, Understanding Human Adjustment: Normal Adaptations Through the Life Cycle, Little, Brown \& Company, Canada, 1983.

[25] A. A. Hidayat, A. Suwandi, Pendidikan Anak Berkebutuhan Khusus Tunanetra: Peserta Didik Berkebutuhan Khusus dengan Hambatan Penglihatan dalam Perspektif Pendidikan dan Layanan, Luxima Metro Media, Jakarta Timur, 2016.

[26] F. Rasyid, Cerdaskan Anakmu dengan Musik!, Diva Press, Yogyakarta, 2010.

[27] A. W. Widjaja, Komunikasi: Komunikasi dan Hubungan Masyarakat, Bumi Aksara, Jakarta, 2002.

[28] R. E. Slavin, Cooperative Learning (Teori, Riset, dan Praktik), Nusa Media, Bandung, 2008.

[29] L. Mazidah, Kesejahteraan Psikologis Tunanetra Dewasa Dini (Studi Fenomenologi pada Mahasiswa Tunanetra Buta Total UIN Sunan Kalijaga Yogyakarta), Universitas Islam Negeri Sunan Kalijaga, Yogyakarta, 2012. 